\title{
METALLOGENESIS IN SOUTH AMERICA: PROGRESS AND PROBLEMS
}

by

\section{Ulrich Petersen}

\begin{abstract}
A provocative and timely scientific review of some of the key metallogenic research problems and challenges in South America today, this paper is presented on the eve of the IUGS Symposium "Metallogenesis in Latin America" (February 4-6, 1980, Mexico City). Co-sponsored by the Consejo Consultivo de Directores de Servicios Geologicos de Latinoamerica, in collaboration with the Mexican Consejo de Recursos Minerales, the IUGS National Committee for Mexico, CGMW's Subcommission for Metallogenic Maps, and with financial support from CONACYT and UNESCO, the Symposium will focus on current research requirements for enlarging and improving the scientific basis for mineral exploration and development in Latin America. Professor Petersen will act as a chief commentator at the Symposium.
\end{abstract}

Introduction

Over the past three decades, considerable progress has been made in understanding both the geological setting and the geochemistry of ore deposits in South America. Extensive regional compilations have been produced,* and a special issue of Economic Geology (v. 72, No. 6, 1977) was dedicated to South American mineral deposits. Other scattered publications have been numerous: one might note the book by Putzer (1976), which provides a balanced and comprehensive review of the subject, and those of Petersen $(1970,1972)$ and Ericksen (1975, 1976) which give summary overviews.

On the whole, the pressure for scientific and fundamental technological progress has not been as intense in South America as one might have anticipated. Because resources in this area are relatively abundant and generally of a higher grade than those of equivalent deposits in industrialized countries, economic and technological problems - capital investment, infrastructure construction, taxation, mining and beneficiation - have been perceived to be more important. Political turmoil has had adverse effects on the private mining sector. New state enterprises have often had to focus on immediate operational necessities and not on long-term fundamental research.

The need for new deposits to replace exhausted ones, and the desire to find better ores for world market competition, has nevertheless spurred geological research. The incentive to gather crucial evidence before existing deposits are mined out has also increased: this has proven vital to extending the lives of deposits and to finding new ones elsewhere. Undoubtedly, some academic studies focussed on South American mines because of their more liberal attitude toward the use of information obtained, while others were possibly motivated by the thought of gaining new insights and applying these to districts in developed countries - districts which were either closed long ago or never developed.

For earth scientists, the challenges in South America are exciting and ongoing. This paper attempts to highlight some of the many metallogenic research problems that remain to be solved.

Porphyry copper - molybdenum deposits

Porphyry copper-molybdenum deposits have commanded a great deal of scientific attention, for the Americas are well endowed with these ores. The study of the EI Salvador deposit in Chile (Gustafson and Hunt, 1975) stands out as a superb example of careful long-term research. Additional investigations of this type - at Chuquicamata, El

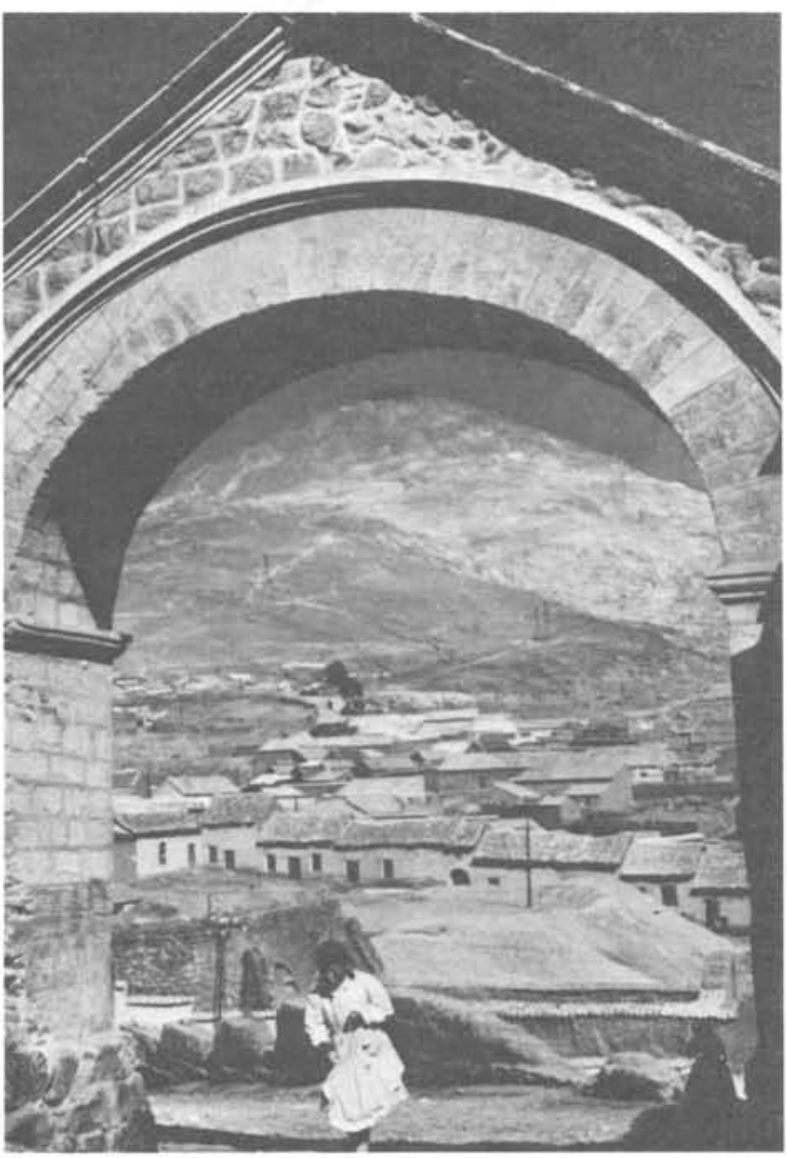

Cerro Rico de Potosi, Bolivia: a major tin-producing area in the Cordillera of South America.

Teniente and Cuajone (see Fig.'s 1 and 2 for place names) would be highly desirable.

Successful future exploration for porphyry-type deposits will require detailed, comparative studies of their alteration haloes, zoning patterns and vertical extent. Their likely upward expressions and their roots are of particular interest, and one wonders if there is any evidence here of deep hypogene leaching, as recently reported from Butte, Montana, U.S.A. (Brimhall, 1978, 1979).

* These include: for Colombia-Wokittel, 1960 and Angulo Carmona, 1978; for Ecuador - Putzer, 1971 and Goossens, 1972 a, b; for Bolivia - Ahlfeld, 1954, and Ahlfeld and Schneider-Scherbina, 1964; for Chile - Zeil, 1964, and Ruiz Fuller et al., 1965; for Argentina - Angellelli, 1950, and Angellelli et al., 1970; for Paraguay Putzer, 1962; for Brazil - Froes, 1973; and for Guyana - Macdonald, 1968, and Lee, 1970. 
Figure 2.

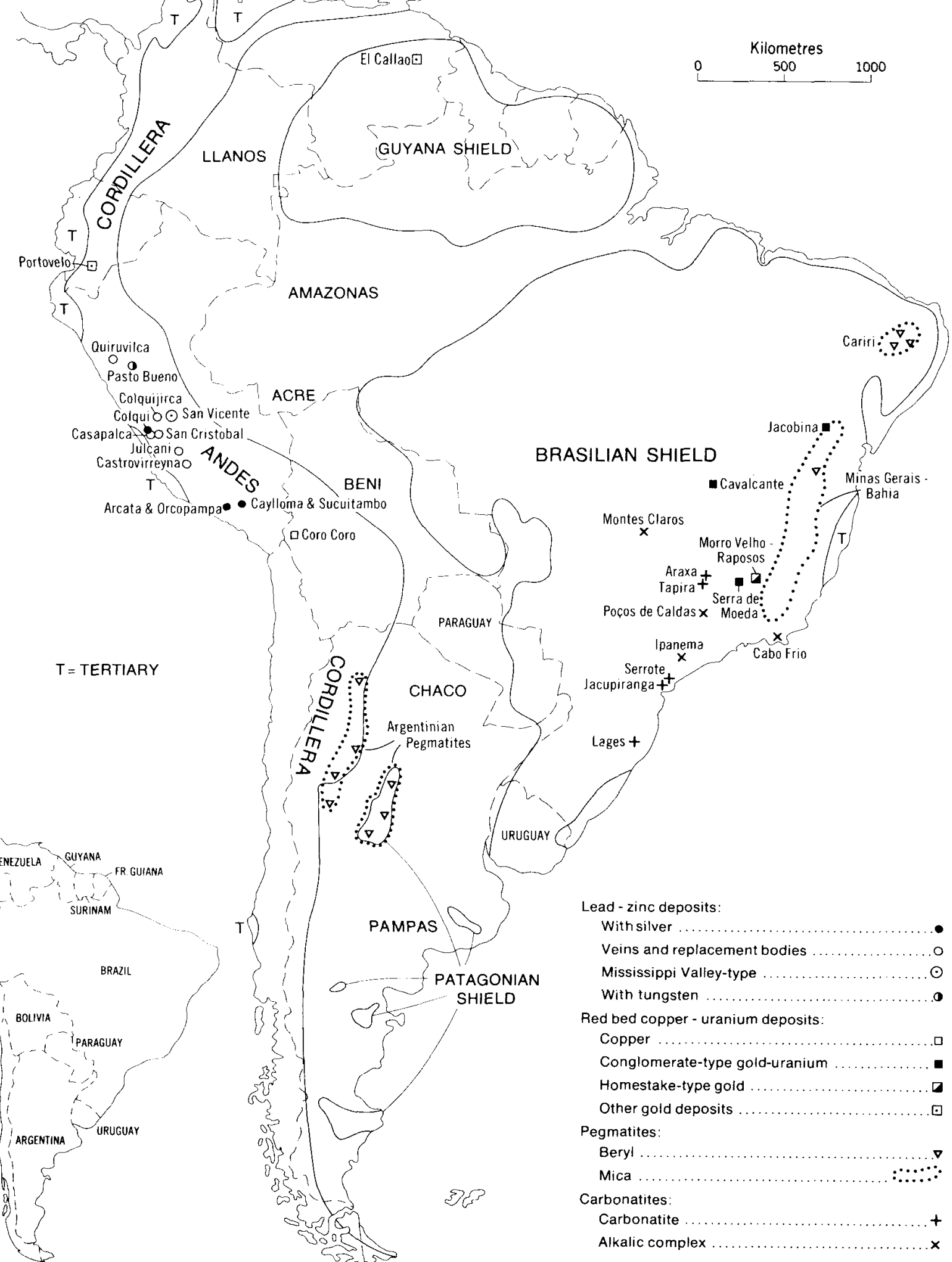

had proceeded an additional $500 \mathrm{~m}$; the productive interval of many porphyry copper deposits may only be in the order of 1 vertical $\mathrm{km}$. Thus, the position of the present-day topographic surface with respect to the presumably favourable Andean batholith-Tertiary volcanics contact interval may decide if one is likely to see the tops, the major zones or the roots of porphyry systems in a given region.

Also worth investigating is the idea that southern Peru and north/central Chile are rich in porphyry copper deposits because there is in this region of the Andes a superposition of the Mesozoic eugeosyncline over a Paleozoic eugeosyncline. This thickened crust of andesitic volcanics could have served as a source of copper for deep, circulating meteoric hydrothermal cells driven by heat from magmas ascending from

the Benioff zone, the upper mantle, or the lower crust.

In 1952, this author observed the remarkable similarity between the chrysocolla ores of Sagasca (Chile) and those of the Exotica ore body at Chuquicamata, recommending that a drilling campaign be initiated to locate a hypothetical porphyry copper deposit which might have been the source of the Sagasca mineralization. The challenge has still to be met, in spite of the strong possibility that the source deposit is probably substantial, high-grade and within $5 \mathrm{~km}$ of the surface mineralization. Further research on the relations between Exotica and Chuquicamata (with particular attention to zonal variations and channel geometry) may help to guide future underground tunneling or surface drilling at Sagasca. 


\section{Skarn copper-zinc-iron-tungsten deposits}

Tungsten-bearing skarns in South America occur almost exclusively in the shield areas of Brazil and Argentina, whereas along the Andes the skarns are noted for their copper, zinc or iron concentrations. Andean skarns are most numerous in Peru, probably because of the predominance of limestone in the Mesozoic stratigraphic section of this country, in contrast to areas further north and south.

A study of the metallogenic map of Peru suggests that the skarn deposits occur in clusters of differing chemistry groups with predominantly copper mineralization alternating with groups of iron mineralization. It would be interesting to see if these variations can be correlated with the chemical composition of the associated intrusives or with the surrounding limestones. Are the temperature-pressure conditions the dominant factors controlling mineralization, or does one resort to speculation about the average composition of underlying Paleozoic (or even Precambrian) rocks?

The Cobriza copper deposit in east-central Peru (Petersen, 1965) presents a special challenge. Here, a $15-30 \mathrm{~m}$ thick sequence of relatively thinly bedded interlayered limestones and shales, within a thick section of shales and quartzites, has been converted to skarn minerals and contains relatively high-grade, chalcopyrite-pyrrhotite-arsenopyrite ore with significant bismuth values. A zonal change from pyrrhotite to magnetite predominance is observed in the deeper levels. There is some controversy over whether this deposit is a conventional hydrothermal skarn or a syngenetic deposit. Because of the low grade of metamorphism and the general accessibility underground, research here could produce significant results which might affect the interpretation of other, more metamorphosed, stratiform copper deposits.

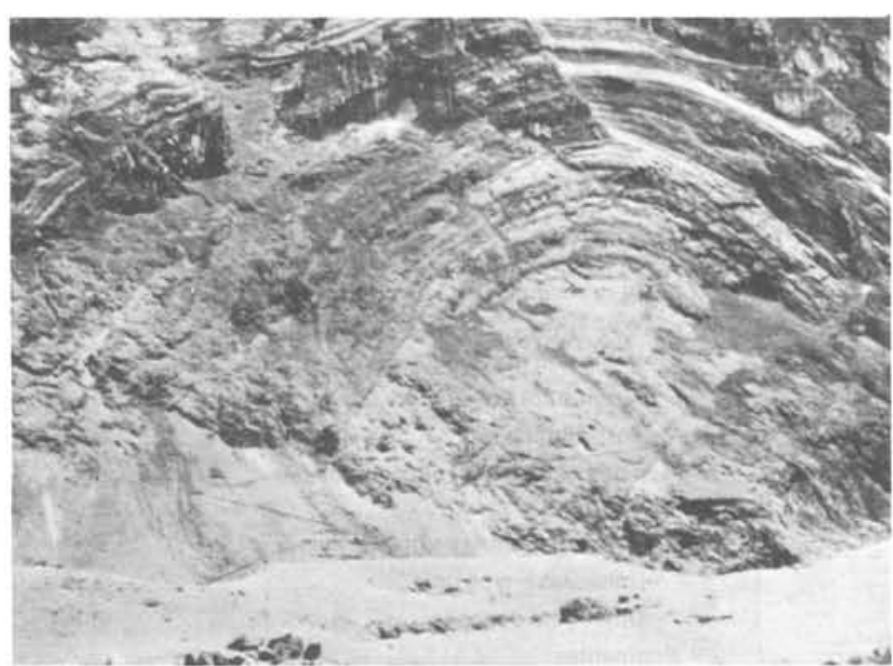

Antamina, Peru: Anticline of Cretaceous limestone replaced by copper and zinc-bearing skarn.

\section{Enargite or zoned copper-zinc-lead-silver deposits}

Although there are some enargite deposits in Ecuador (Pilzhum), Bolivia (Laurani) and Argentina (Capillitas, Sierra de Famatina), most seem to be concentrated in Peru (Quiruvilca, Cerro de Pasco, Colquijirca, Huaron, Morococha, Yauricocha and Julcani). Recent detailed studies at Cerro de Pasco (Einaudi, 1977) and Julcani (Petersen et al., 1977) have added to the understanding of this group. However, the reasons for the high concentration of these deposits in Peru (when elsewhere - at Butte, Tintic and Magma in the U.S.A. and in Chinkuashih, Taiwan - such occurrences are relatively isolated), still remain to be clarified.

The Andean arsenical metallogenic anomaly is further emphasized by the presence of enargite among the hypogene ore minerals of several large and high-grade porphyry copper deposits in Chile (Chuquicamata, El Salvador, Potrerillos, La
Americana-Rio Blanco, and El Teniente), because this mineral is not common in deposits of this type elsewhere. A large-scale geochemical rock sampling program along selected transects in central Peru, southern Peru/northern Chile/Bolivia and central Chile/Argentina could shed light on whether common sediments and/or igneous rocks reveal a regional geochemical arsenic anomaly or not.

At Butte, disseminated copper mineralization has been discovered in depth (Meyer, 1965) and a case is now being made for the overlying enargite-type mineralization having been largely derived from it (Brimhall, 1978, 1979). At Morococha, the centrally located intrusives cut by enargite veins have also disseminated copper mineralization. It would be interesting to know if this mineralization is older (as at Butte) and more extensive in depth: the outcome of such a study may well influence the potential for deep exploration at other enargite-type deposits.

\section{Stratiform copper-zinc-lead deposits}

The search for Kuroko-type copper-zinc-lead deposits has lately caused a number of geologists to scrutinize the Andes. Stratiform volcanogenic base metal deposits have been identified in the Mesozoic eugeosynclinal sequences in Ecuador (La Plata-Toachi), Peru (Raul-Condestable: Ripley and Ohmoto, 1977; Wauschkuhn, 1978; Ohnsmann et al., 1978; Ripley and Ohmoto, 1979) and Chile, but not in the predominantly continental Tertiary volcanics. A careful delineation of paleoenvironments, with particular emphasis on submarine volcanism for appropriate subdivisions of the Precambrian, Paleozoic, Mesozoic and Tertiary, might well help to focus this exploration effort.

Two striking metallogenic puzzles are posed by the relative scarcity of production (as compared to North America) from Mississippi Valley-type lead-zinc-barite-fluorite deposits, and the absence of Zambian-type copper deposits in spite of the presumed pre-continental drift unity of South America and Africa. Research is needed to show if the answer to the first puzzle lies in the scarcity of platform limestones, or have such lead-zinc-barite-fluorite deposits been difficult to recognize because of their lack of prominent gossans or of significant geophysical response? Perhaps once identified, they have simply proved uneconomic to justify commercial operations in the jungles of Brazil and Peru.

As for the Zambian-type deposits, have they remained unrecognized because of surface leaching of copper by the intensive rainfall and weathering conditions of Brazil? Or is there some geological-geochemical reason for the absence of these ore deposits?

\section{Lead-zinc veins and mantos}

Again, Peru is the preferred habitat for lead-zinc veins and mantos. This is not surprising if one considers the predominance of limestone in the Mesozoic stratigraphic section of this country. The more interesting metallogenic questions here concern the origin of the lead-zinc and the hydrothermal fluids which transported them. The $\delta D$ and $\delta 0^{18}$ studies carried out at the Colqui mine (Kamilli and Ohmoto, 1977) suggest that the fluids which deposited the base metals were formation waters interacting with Permian or Mesozoic evaporites; the studies at Casapalca (Rye and Sawkins, 1974) and Pasto Bueno (Landis and Rye, 1974) have pointed toward their being magmatic-hydrothermal fluids.

Geologists of the European school interpret a number of stratiform deposits, such as those at San Vicente (Schultz, 1973; Levin and Amstutz, 1973), and Colquijirca (Amstutz and Lehne, 1978), as syngenetic, and postulate that most veins and mantos represent remobilization products from such syngenetic deposits. Convincing evidence to support such speculation is still lacking: most of this work has been based on ambiguous textural evidence on the stratiform deposits, and lacks credible connections between these and the veins or mantos. Fur ther detailed studies, complemented 
y comprehensive geochemical observations, are needed to est these ideas.

\section{Indean silver deposits}

Jur understanding of silver deposition in the Andes has rogressed through studies at Colqui (Kamilli and Ohmoto, 1977), Casapalca (Wu and Petersen, 1977) and Julcani Petersen et al., 1977). Continuing work at these and other nines (Orcopampa, Arcata, and Castrovirreyna), should roduce some interesting results. Aside from silver concenrations attributable to residual enrichment in the oxide zone, or due to supergene enrichment, it appears that there are two principal modes of hypogene silver ore deposition: (1) through boiling of the ore fluid in a narrow vertical interval (as at Colqui and Arcata), and (2) through gradual deposition of silver minerals over a significant interval along a contorted ore zone (such as at Julcani, Orcopampa, Castrovirreyna and Casapalca).

In the second case, additional information should be sought on the following: (a) the general attitude of the ore zone, in order that it may be followed laterally or downward, as the case may be; (b) the criteria for recognizing the initial and final deposition fronts of the ore zone, in order to avoid useless exploration beyond these limits; and (c) the possibility of using the zoning of non-economic elements above or below the ore zone in order to estimate its position and guide exploration.

The most effective means of accomplishing the first two objectives might be through zoning studies, involving detailed compositional determinations of silver minerals capable of solid-solution variations (such as tetrahedrite and the "ruby silvers"). If the silver mineralizaton is only part of a more complex base metal paragenesis, then metal ratio studies, like those developed at Julcani (Goodell and Petersen, 1974; Petersen et al., 1977), can be of considerable help. One must assume, however, that the solutions which precipitated silver followed roughly the same paths as the solutions which also precipitated the base metals. The information available to date suggests that this assumption is generally valid, at least for practical applications, but further research is needed.

When silver mineralization constitutes only a by-product of the base metal mineralizaton (as at Casapalca, Castrovirreyna, Colqui or Julcani), then the continuation of the base metal mineralization beyond the limits of the silver zone becomes a crucial question. Conversely, if silver is the main or only economic product (as at Orcopampa and Arcata), then the crucial question (aside from the extent of the silver zone) concerns the possibility of encountering a base metal zone inward in the zoning sequence. At present, this problem is tackled through risk exploration in the core of a zoning sequence, in the most important ore structure, using metal-ratio and solid-solution composition contours as guides to reach the deepest zonal elevation at the lowest cost. Research directed at improving this approach is highly desirable.

There is commonly a distinct silver stage either preceding (as at Colqui) or following (as at Casapalca) the main base metal mineralization. The Colqui study (Kamilli and Ohmoto, 1977) has indicated that meteoric waters alternated with formation waters in the same vein structure, the former leading to silver ores, the latter to base metal ores. At Casapalca, Rye and Sawkins (1974) concluded that magmatic waters led to the formation of base metals, but that meteoric waters may have followed the silver stage. Clearly, additional fluid inclusion and isotopic studies are required to test the validity of meteoric water involvement in silver ore deposition.

"Pure" silver deposits (like Orcopampa, Arcata, Caylloma, and Sucuitambo) are commonly found in Tertiary volcanic environments where it is likely that a meteoric water cell may not have penetrated the underlying Mesozoic sediments, or where waters from these sediments or deep magmatic fluids would have had to travel considerable distances before reaching exposed parts of the veins.
Conversely, silver-lead-zinc-copper deposits (like Casapalca and all the enargite deposits, except for Julcani and Quiruvilca) are within the Central Mesozoic sedimentary fold belt (Petersen, 1965), in positions where one assumes that the Tertiary volcanic cover was not very far above and has since been removed by erosion. Veins in such an environment would more likely have been invaded alternately by fluids from different sources: (i) meteoric waters which circulated predominantly through the overlying volcanics and tended to deposit silver ores, and (ii) formation or magmatic waters which circulated through the Mesozoic sediments, tending to deposit lead-zinc ores.

At Julcani, the mineralization is in the volcanics, but it is evident that any meteoric hydrothermal cell would have had to involve the underlying Mesozoic and Paleozoic sediments. At Colqui and Quiruvilca, mineralization is also in Tertiary volcanics, though it is not possible to estimate on geological evidence alone how far down the Mesozoic sediments might be. If this meteoric water-formation, water-magmatic water alternation is confirmed by other investigations, then one should know why meteoric waters tend to deposit silver and not base metal ores, or whether the dominant controlling factor is the contrast between predominantly volcanic and sedimentary country rocks.

\section{Tin-tungsten deposits}

Traditionally, the mention of tin and tungsten in South America evoked an image of the well-defined Bolivian belt of deposits, stretching from the southeasternmost part of Peru through Bolivia to northern Argentina. Our understanding of the physico-chemical conditions of their formation, through fluid inclusion investigations, has improved in recent years (Kelly and Turneaure, 1970). Establishment of the porphyry tin model (Sillitoe et al., 1975) and recognition of manto-type tin deposits (Schneider, 1975; Lehmann, 1979) have proved to be great scientific advances leading to the discovery of additional ore reserves.

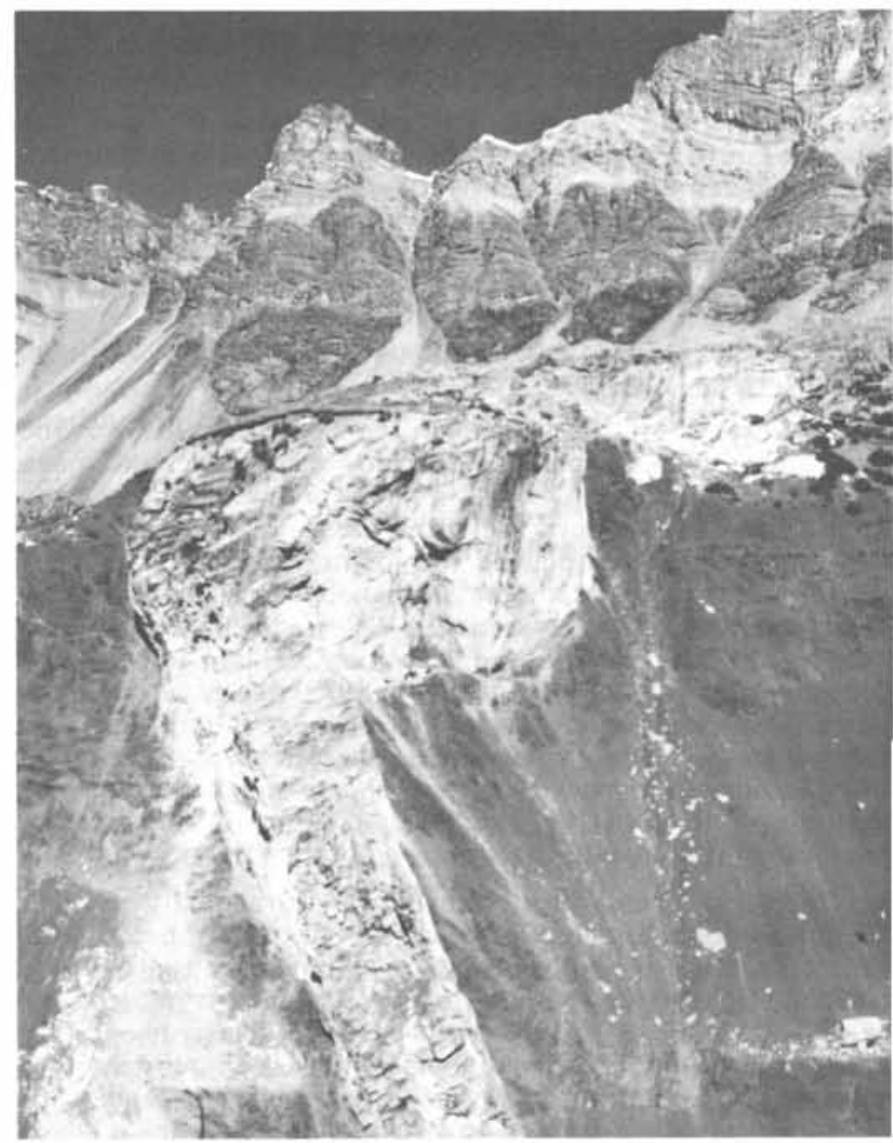

Mina Ragra, Peru: Dike cutting Tertiary red-beds exposed on open pit wall. Vanadium-bearing, organic-rich sediments are in lower part of the photograph. 
The marked difference between the mineralogy of the northern and southern Bolivian tin deposits has been observed for some time. It was explained in terms of depth of emplacement or erosion level, because in the north the ore deposits are clearly associated with partly unroofed batholiths, whereas in the south their association is with subvolcanic stocks. Recent radiometric dates (summarized by Lehmann, 1979) have shown that there is a large decrease in ages from north to south for the igneous rocks to which the tin-tungsten ores appear to be related.

Scattered economic concentrations of tin and tungsten are found in Argentina (Angellelli, 1950; Angellelli et al., 1970), and some tungsten deposits occur in Peru (Pasto BuenoTamboras, San Cristobal, Julcani). Indications from fluid inclusion and isotopic studies at Pasto Bueno (Landis and Rye, 1974) relate tungsten deposition to meteoric water influx. If this is so, the question as to why meteoric water may deposit silver in some veins and tungsten in others becomes intriguing.

At Pasto Bueno, the veins are within greisenized intrusives and in Mesozoic sediments; at San Cristobal they are in Paleozoic sediments and volcanics; in Julcani - mineralization is in Tertiary volcanics, but in close proximity to underlying Paleozoic and Mesozoic sediments. In all three districts, therefore, meteoric waters would have had ample opportunity to interact with Paleozoic (or Mesozoic) sediments.

Both in Peru and in Bolivia, the mineralogy of the tintungsten veins is such that detailed zoning studies using metal ratios and solid-solution compositional variations ( $\mathrm{Fe} / \mathrm{Mn}$ in wolframite; $\mathrm{Fe}$ and $\mathrm{Cd}$ in sphalerite; $\mathrm{Ag}, \mathrm{Cu}, \mathrm{As}$ and $\mathrm{Sb}$ in tetrahedrite and other sulphosalts; $\mathrm{Sr} / \mathrm{Ba}$ in barite; $\mathrm{Ca} / \mathrm{Mg} / \mathrm{Fe} / \mathrm{Sr}$ in carbonate) are likely to be successful. At San Cristobal and Julcani, wolframite mineralization appears to form an integral and congruent part of the base-metal and silver zoning pattern, and studies are in progress to confirm this. Whether the wolframite was also deposited from meteoric water, as at Pasto Bueno, or from magmatichydrothermal fluids, as is commonly believed for this mineral, still remains to be established.

Since World War II, the Paraiba tungsten-tin and the Rondonia tin-tungsten districts have attracted attention. Although much of the production has come from placers, the primary deposits are sufficiently well known to suggest that a careful geochemical study (including fluid inclusion and isotopic investigations) should be carried out in these two districts to allow for a proper comparison to be made with the corresponding deposits in Bolivia, Portugal, Cornwall and the Erzgebirge.

The discovery of the Rondonia tin deposits led to the speculation that this Precambrian district could have extended further east. Its erosion products might have formed (in what is now Bolivia) Paleozoic placers, which, upon metamorphism produced the manto deposits (Schneider, 1975). Subsequent metamorphism, igneous activity and associated hydrothermal convection cells would have mobilized the tin into the Mesozoic and Tertiary veins. However, a recent geochemical study (Lehmann, 1979) has shown that the manto deposits are not fossil tin placers: they form an integral part of the vein-type mineralization. Detailed zoning studies are now required to connect the veins and mantos and to help in guiding exploration of the mantos, which might hold substantial reserve potential.

The Paleozoic country-rocks reveal no tin anomaly relative to equivalent rock types elsewhere. It cannot be argued, therefore, that the erosion of the Rondonia tin deposits provided a higher geochemical background which predestined the formation of younger hydrothermal tin veins. If one still accepts the "remobilization" theory, one would have to either postulate the anatexis of a tin-rich Precambrian basement, or prove that the scavenging hydrothermal cells penetrated such a basement.

On the other hand, the aforementioned detailed geochemical study discovered that the Bolivian country-rocks are distinctly anomalous in boron by virtue of finely disseminated tourmaline. This brings up two points: first, that this tourmaline may be derived laterally by erosion from the exposed Precambrian basement, and may be widely distributed in the Paleozoic sediments by virtue of its specific gravity being similar to other rock forming minerals. The detrital cassiterite, on the other hand, would be in a much more restricted location (not sampled during the geochemical study) but possibly leached by hydrothermal cells restricted to the Paleozoic sediments. Secondly, the surface and near -..race waters might have become unusually enriched in boron as a consequence of the weathering of the tourmaline: upon evaporation, these waters might have contributed to the unusual richness in borates of the salares.

\section{Gold and Uranium Deposits}

The possibility of locating another Witwatersrand or Blind River type district continues to provide one of the great incentives to mineral exploration in eastern South America today. Gold has been mined in the past from pyritic conglomerates, like those in South Africa and Canada, at the Serra de Jacobina in Brazil (Cox, 1967). Uranium was found in the Jacobina reefs shortly after World War II and recently in other conglomerates (McNeil, 1979) at the Serra de Moeda (Minas Gerais) and near Cavalcante (Goias). The objective of these exploration efforts is to learn how to locate, recognize and explore in detail these ore bearing conglomerates.

It is presumed that the gold accumulates in placers which, when properly plotted, might lead to the general outcrop or sub-outcrop region of the economic conglomerates; careful analysis of the detrital quartz might reveal fragments with radiation damage. The intense Brazilian rainfall probably leaches much of the uranium from the outcrop, but it may be trapped nearby in organic-rich soils to produce radiometric anomalies. Oxidation of pyrite may yield a recognizable gossan, or, if leached, a "tell-tale" boxwork. Once an attractive conglomerate is located, further exploration by drilling might rely on South African and Canadian experience. Careful studies of the Jacobina district could provide more accurate guidance for exploration elsewhere.

More studies of iron formation may be justified in terms of locating additional deposits of (i) Homestake-type gold ores, (ii) Jacutinga-type gold ores, or (iii) uranium enrichments. Morro Velho (St. John del Rei) was once a major producer of gold and the deepest mine in the world. Recent studies (Tolbert, 1964) have strengthened the idea that the Morro Velho-Raposos gold deposits are of the Homestake-type, that is, they were enriched during the metamorphism of a carbonate iron formation. Given the great extent of iron formations in Brazil, chances are good that other Homestake-type deposits occur in them.

Furthermore, the extraordinary down-dip extent of these ores increases the chance that they may intersect the surface at some point. Hence, a detailed geochemical-isotopic study of the Morro Velho-Raposos ores is needed to confirm their similarity with Homestake, and to investigate the surface geochemical dispersion (Au, As) as well as the geophysical expression of these ores. Further comparison with Homestake should indicate if a certain metamorphic grade is optimal in producing economic gold concentrations.

The Jacutinga gold ores occur in brittle-pulverulent itabirite leached of its $\mathrm{SiO}_{2}$ content in weathering zones up to $130 \mathrm{~m}$ deep (Putzer, 1976). The gold concentrations form "goldlines" parallel to bedding, thought to have been formed by supergene enrichment, the gold having been derived from gold-quartz veins in the iron formation. This mode of formation is supported by the observation that at Gongo Soco (near Caete) 12.8 tor.s of gold were mined between 1826 and 1856 from a $90 \mathrm{~m}$ wide manganiferous itabirite: it is well known that manganese oxides favour the supergene mobility of gold. Further sharpening of this model may lead to the identification of additional Jacutinga-type gold ores, which 
may otherwise be overlooked in large-scale mechanized mining for iron or manganese ores.

This leads to a rather speculative, but hopefully not absurd idea: hematite iron formations (particularly if they are manganiferous) and their weathered equivalents may be instrumental in carrying oxidized meteoric waters to considerable depths, analogous to red-beds and "clean" sandstones. Any uranium scavenged from surrounding granitic intrusives/gneisses or from the iron formation itself would precipitate, by reduction in depth, upon reaching the water table, or by appearance of magnetite, ferromagnesian minerals or some other reducing mineral contained in the fresh iron formation or appearing as a result of sedimentary facies changes.

Among the sandstone-type deposits one notes that there is a metallogenic change from uranium predominance in Argentina to copper predominance in Bolivia, Peru and Colombia (Petersen, 1970). This is puzzling because there are other types of copper deposits in Argentina and no other particular evidence for an anomalously low geochemical abundance of uranium in Bolivia, Peru and Colombia. Furthermore, there is only one red-bed vanadium deposit in this entire belt (at Minas Ragra, Peru). No doubt, one can recognize on an Eh-pH diagram conditions which would leach, transport or precipitate uranium, vanadium and copper differentially (Garrels and Christ, 1965) or arrive at this same result by other solubility considerations. More pertinent, however, is the question of whether these theoretical inferences actually apply in the field. What are the specific mineralogical-petrographical controls?

One could start by trying to explain the baffling contrast at Coro Coro (Bolivia) between the chalcocite bearing mantos on one flank of the "anticline" and the native copper bearing mantos on the other flank (Ahlfeld and Schneider-Scherbina, 1964). One can show, for example, that the presence of a calcite cement in a hematitic red-bed tends to buffer the fugacity of sulfur to such a low value that native copper instead of chalcocite is likely to precipitate. A demonstration that the native copper-bearing beds contained a calcite cement prior to the circulation of the copper-bearing solutions (whereas chalcocite-bearing beds did not have it in sufficient amounts) would provide a credible indication of what constituted the pertinent mineralogical-petrographical control. The questions of whether this is conceivable over the distances involved from Colombia to Argentina or if climatic control plays a part here, remain to be studied. Perhaps it is simply a question of supply of uranium, copper or vanadium to the groundwaters.

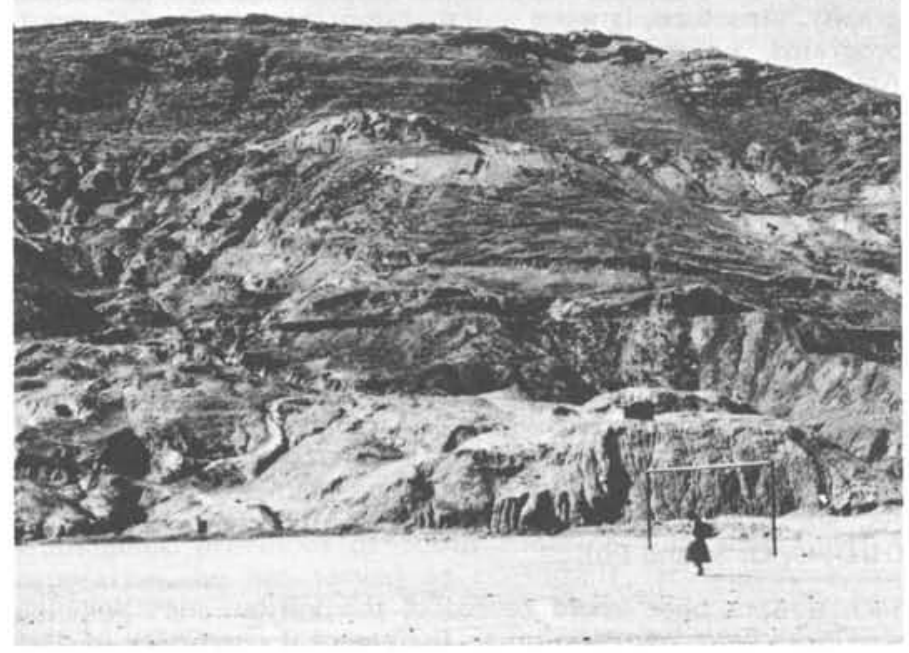

Coro Coro, Bolivia: White outcrops mark trace of mineralized bed.
The recent rise in gold prices will undoubtedly revive and intensify mining of the numerous placers throughout South America; it might also provide an opportunity to carry out studies directed at identifying the primary sources of these placers. Undoubtedly, many will turn out to be uneconomic quartz-gold veinlets in metamorphosed pelites, but some would surely lead to equivalents of the Witwatersrand, Homestake, Mother Lode, Kirkland Lake, Porcupine, Kalogoorlie or Bendigo districts. This research should be aimed at stream sediments and placer minerals which might locate a series of placers corresponding to a major primary district heretofore unrecognized.

Another possible off-shoot of the rising gold prices might be the reactivation of apparently exhausted gold districts, such as El Callao (Venezuela) and Portovelo (Ecuador). Detailed zoning and ore control studies would insure that these districts are mined out efficiently. This may also provide the opportunity to test the Portovelo district for uranium concentrations in view of the fact that lollingite, rammelsbergite and $\mathrm{Ag}-\mathrm{Bi}$ minerals have been reported from its ores (Putzer, 1971).

\section{Pegmatites}

Pegmatites represent relatively small targets with irregular shapes and erratic mineralization, inconspicuous hypogene alteration haloes and oxide zones (due to their low sulfide content), and poor chances for geophysical detection (low sulfide content, rare pyrrhotite or magnetite). Nevertheless, some pegmatites are sufficiently large and/or rich to be economically mineable today, and useful primary alteration haloes are being revealed by careful investigations in Canada. Hence some research on this topic may be justified.

Tradition has held that economic pegmatites crystallize from residual fluids escaping from solidifying plutons. Because of the scarcity of pegmatites surrounding high-level plutons (one notes, for example, the common absence of pegmatites associated with the Andean batholith and with the numerous igneous stocks or volcanic necks along the Andes), many geologists envisage pegmatites forming in deep environments at the time of anatexis.

A comparative study of the various pegmatite provinces of South America could test the concept of pegmatites being associated with anatectic granites/gneisses and not with high level-intrusive bodies. It is possible that pegmatites result from the recrystallization of incipient melting, which coalesced in the center of the "hot spot" to form the batholith with which the pegmatites appear to be associated. Simple pegmatites, therefore, conform in composition to minimum melting mixtures. Activity of water gradients or hydrothermal cells induced by the hot-spot would hydrate some melts more than others, depending on the availability of water and on permeability distributions. This hydration process could supply the minor elements which characterize complex pegmatites.

The South American pegmatite provinces (Putzer, 1976) have specific predominances of economic minerals (Cariri: Be-TaLi; Minas Gerais - Southern Bahia: mica, precious stones; Central Bahia: emeralds; Guianas: Ta-Nb-Sn; Argentina: BeLi). Even within a given province (Minas Gerais - Southern Bahia) there are notable variations. Again, a comparative geochemical investigation to see if one can relate these variations to the chemistry of the country rocks, the central (anatectic) plutons, or the hydrothermal fluids would be extremely interesting.

Evidence from the Appalachians (Cameron et al., 1949, 1954; Morgan, 1972) and Black Hills (Norton, 1975) in the U.S.A. suggests that economic pegmatites are closely related to the metamorphic sillimanite isograd. Mapping the metamorphic isograds in the pegmatite regions of South America would test possible similarities; this information could be used to evaluate if certain pegmatite districts have been completely explored, or if others remain undiscovered due to soil, vegetation or later sedimentary/volcanic rock cover. 
Obtaining radiometric ages for the Argentinian and Guianian pegmatites might show if they formed at the same time as the Cariri and Mina Gerais - Southern Bahia pegmatites in Brazil (50 and $550 \mathrm{Ma}$ respectively - Putzer, 1976).

\section{Alkalic Complexes and Carbonatites}

Alkalic complexes and carbonatites have been popular exploration targets during the past two decades: they can be spotted better than most other ore deposits on aerial photographs for they are relatively large, have characteristic structures and indicative soil/vegetation cover. They may be detected with radiometric surveys, approached by studying their characteristic and resistant minerals in stream sediments, and recognized by the fenitization of the country rocks. Exploration efforts are justified by the potential prizes: copper in Palabora, South Africa; rare earths at Mountain Pass, California; niobium at Araxa, Brazil; uranium and thorium at Pocos de Caldas, Brazil.

Further research may be warranted into the abrasion characteristics (size and rounding) of their characteristic minerals in stream sediments of rivers emanating from the alkalic complexes and carbonatites. This information could be used not only in the search for deposits in the Brazilian and Guiana shields (including the eastern slopes of the Andes), but also in applications in North America, Eurasia and Africa.

It would also be desirable to continue the age dating and general chemical characterization of known alkalic complexes and carbonatites. The ages for Brazil (Putzer, 1976) appear to fall into two groups: $50-82 \mathrm{Ma}$ and $122-150 \mathrm{Ma}$. Since the trap-basalts of the Parana basin are 119-147 Ma old, it appears that the melanocratic alkalic complexes (Jacupiranga, Ipanema, Serrote) are related to this magmatic episode.

This, however, leads to several puzzling questions: (i) Were the younger leucocratic (Pocos de Caldas, Lages and Cabo Frio) and melanocratic (Araxa, Tapira, Catalao and Montes Claros) alkalic complexes not associated with trap basalts? (ii) Were the $50-80 \mathrm{Ma}$ trap basalts by chance not dated, or have they been eroded away so that only the older ones could be dated? (iii) Why have we not seen examples of the younger alkalic complexes cutting the Paraná basalts? (iv) Did the thick package of Parana basalts effectively prevent the ascent of alkalic complexes and carbonatites through them?

It would also be of interest to establish if there is any systematic relation of chemistry to distribution or age. All the older complexes are melanocratic, whereas the younger ones may be either leuco- or melanocratic. Furthermore, U, $\mathrm{Th}, \mathrm{Zr}$ and $\mathrm{F}$ seem to prevail among the leucocratic complexes. Among the melanocratic complexes, the older ones tend to be richer in $\mathrm{P}$ and $\mathrm{Fe}$, whereas the younger ones tend to have $\mathrm{Nb}$.

\section{Diamonds}

One of the fascinating problems of South American metallogeny concerns the primary sources of the many placer diamonds which have been found. After Bernardo de Fonseca Lobo discovered placer diamonds in 1725, Brazil became the largest diamond producer in the world. Diamonds were discovered in South Africa in the third quarter of the nineteenth century. Since then, the South Africans and the Russians have managed to locate the primary sources of the diamonds; similar efforts in South America have remained fruitless.

Possibly the problem lies with the observations made at different localities: in South America the diamonds appeared to be derived from conglomerates whose age could reach as far back as the Precambrian. The conclusion was that these diamond-bearing sediments cover the diamond pipes, making them difficult or impossible to locate precisely.

However, the following points should be noted: (1) if the conglomerates derived their diamonds from kimberlite pipes, the latter should be located beside (and upstream) rather than below these conglomerates; (2) in the Triangulo Mineiro and elsewhere, many diamonds are almost perfect octahedra, indicating a very short transport distance; (3) in the major districts (Triangulo Mineiro, Diamantina and Chapada Diamantina) the location of the placers points to rather limited source regions; (4) in the Triangulo Mineiro, the placer mineral suite includes pyrope, magnesian-ilmenite and chrome-diopside - characteristic minerals of kimberlite pipes used to locate the Siberian diamond pipes; (5) in 1973, a West German geological-geophysical mission drilled a geophysical anomaly, encountering an ultrabasic explosive breccia containing pyrope and indicating the existence of kimberlite; and (6) in the rainy tropical climates of Brazil and Guiana, one would expect a kimberlite to weather quite deeply, probably in excess of $100 \mathrm{~m}$, making it difficult to recognize a pipe.

On the basis of the above mentioned, it seems justifiable to investigate more carefully the type of soils which would result from kimberlite weathering and their likely vegetation characteristics. Combining this information with locations, sizes and rounding of diamonds, pyrope, chrome-diopside and picro-ilmenite from placers and conglomerates should allow the selection of limited areas which can be surveyed magnetometrically, and then drilled. If this approach succeeds in the Triangulo Mineiro, it can be applied to other areas. The most difficult situation is perhaps in Guiana, where the characteristic kimberlite minerals (pyrope, chrome-diopside and picro-ilmenite) have not been recorded; some geologists have even argued that the source pipes are located in what is now Africa (Reid, 1974).

\section{Regional Geology and Geochemistry}

A number of questions need to be resolved on a regional scale. Since ore deposits are a product of their environment, it would be desirable to compile a series of paleogeographic maps analogous to those contained in the Shell Atlas for North America (Cook and Bally, 1975). A clearer representation of intrusive and extrusive igneous events would be useful. Such an atlas would outline favourable environments for several types of deposits (volcanogenic massive sulfide, black shales, Mississippi Valley-type, iron-manganese, uranium), and place constraints on the possible role of underlying evaporite or eugeosynclinal sequences. For example, it would focus attention on the position of the Paleozoic eugeosynclinal belt in Argentina and Chile, as well as its apparent truncation by the present Chilean coast. It might resolve the question of whether or not the belt extended seaward of the present Peruvian coast (where there is now an oceanic trench) and reappeared in northern Ecuador and coastal Colombia.

It would be difficult to make significant progress on the metallogeny of Precambrian and Paleozoic ore deposits without further clarification of the corresponding regional stratigraphy, structure, igneous and metamorphic events. Current programs of radiometric age determinations in South America should be continued to help clarify a number of age relations which are still in doubt, and to contribute to our understanding of the shape of various mineral provinces. This data base will someday become large enough to test the various hypotheses linking oceanic plate motions to igneous activity along the Andes.

From a metallogenic point of view, an appealing major project would be to carry out three geochemical transects across the Andes: through central Peru, through northern Chile/Bolivia, and through central Chile/Argentina. They might involve an extensive rock sampling program to evaluate (a) transverse changes in major elements ( $\mathrm{Na}, \mathrm{K}, \mathrm{Ca}, \mathrm{Si}$, $\mathrm{Al})$; (b) transverse variations in trace elements $(\mathrm{Cu}, \mathrm{Pb}, \mathrm{Zn}$, $\mathrm{As}, \mathrm{Sb}, \mathrm{Sn}, \mathrm{W}, \mathrm{Ag}, \mathrm{Au}, \mathrm{U})$; and (c) isotopic characteristics $(\mathrm{H} / \mathrm{D}, \mathrm{C}, \mathrm{O}, \mathrm{Sr}$ and $\mathrm{Pb})$.

Such a data base could reveal if the various metallogenic provinces bear any relation to the regional chemistry of the upper crustal rocks, and may provide some geochemical information on deeper levels. It may, for example, reveal if 
there is a regional arsenic anomaly which might help to explain the common occurrence of arsenic-bearing minerals, particularly enargite. Or, it might point to heretofore unsuspected relations, such as the boron anomaly mentioned above and borate deposits in Bolivia. It would further test the apparent absence of a tin anomaly in Bolivia. It might even identify uranium-rich granites or discover an inconspicuous manto deposit, like Cercapuquio (Peru) or the Bolivian tin mantos.

Should the geochemical surveys described give positive results, one might proceed from there to more extended studies to determine if the metallogenic provinces, as currently outlined, are "complete", or if they were partially eroded or covered by later sediments/volcanics or soil/vegetation. Such investigations could throw light into the intriguing idea that certain elements are concentrated in more or less equant provinces in the continental crust, and were then mobilized by hydrothermal cells associated with intrusives generated primarily by oceanic plate subduction, and thus leading to almost linear provinces, such as the Bolivian tin belt.

\section{References}

Ahlfeld, F., 1954, Los yacimientos minerales de Bolivia: Bilbao, Imprente Ind., 277p.

Ahlfeld, F., and Schneider-Scherbina, A., 1964, Los yacimientos minerales y de hidrocarburos de Bolivia: Bol., Dept. Nac. Geol., No. 5, 388 p.

Amstutz, G.C., and Lehne, R.W., 1978, Genese der polymetallischen Lagerstå̀tte Colquijirca, Peru: 6 . Geowissenshcaftliches Lateinamerika Kolloquium, Stuttgart, Abs., p. 6.

Angellelli, V., 1950, Recursos minerales de la Republica Argentina; 1, yacimientos metaliferos: Inst. Nac. Invest. Cienc. Nat., Buenos Aires, Rev., Cienc. Geol., t. 2, 543 p.

Angellelli, V., Fernandez Lima, F., Herrera, A., and Aristarain, L., 1970, Descripción del mapa metalogenético de la República Argentina: Dirección Nac. Geol. y Mineria, Anales 25, Buenos Aires, $172 \mathrm{p}$.

Angulo Carmona, R. (ed.), 1978, Recursos minerales de Colombia: Min. de Minas y Energiá, INGEOMINAS, 544 p.

Brimhall, G.H., 1978, Mechanisms of vein formation at Butte, Montana: Element recycling by hypogene leaching and enrichment of low-grade Ksilicate protore: Abstract, Econ. Geol., v. 73, p.1389.

Brimhall, G.H., 1979, Lithologic determination of mass transfer mechanisms of multiple-stage porphyry copper mineralization at Butte, Montana: Vein formation by hypogene leaching and enrichment of potassium-silicate protore: Econ. Geol. v.74, No. 3, p. 556-589.

Brüggen, J., 1950, Fundamentos de la Geología de Chile: Inst. Geogr. Militar, 374 p.

Cameron, E.N., et al., 1949, Internal structure of granitic pegmatites: Econ. Geol., Monograph No. $2,115 \mathrm{p}$.

Cameron, E.N., et al., 1954, Pegmatite Investigations 1942-45, New England: U.S. Geol. Survey, Prof. Paper 255, $352 \mathrm{p}$.

Cook, T.D. and Bally, A.W. (eds.), 1975: Stratigraphic Atlas of North and Central America: Princeton Univ, Press, Princeton, N.J., 272 p.

Cox, D.P., 1967, Regional environment of the Jacobina auriferous conglomerate, Brazil: Econ. Geol. v. 62 , p. $773-780$.

Einaudi, M.T., 1977, Environment of ore deposition at Cerro de Pasco, Peru: Econ. Geol., v. 72, p.893. 924.

Ericksen, G.E., 1975, Metallogenic provinces of the southeastern Pacific region: Open-file report 75 263 , U.S. Geol. Survey, 52 p.

Ericksen, G.E., 1976, Metallogenic provinces of southeastern Pacific region: Am. Assoc. Pet. Geol., Mem. 25, p. 527-538.

Froes Abreu, S., 1973, Recursos minerais do Brasil: v. I and II, Instituto Nac. de Tecnol., Univ. de Sao Paulo, I: p.1-320; II: p.321-754.

Garrels, R.M., and Christ, C.L., 1965, Solutions, Petersen, U. 1965, Regional geology and major ore minerals, and equilibria: Harper \& Row,
New York, 450p.

Goodell, P., and Petersen, U., 1974, Juicani mining district, Peru: a study of metal ratios: Econ. Geol., v. 69, p. 347-361.

Goossens, P., 1972 a, Los yacimientos e indicios de los minerales métalicos y no-métalicos de la Repú blica del Ecuador: Dept. Facul. Cienc. Natur., Guayaquil, $123 \mathrm{p}$.

Goossens, P., 1972 b, Metallogeny in Ecuadorian Andes: Econ. Geol., v. 67, p. 458-468.

Gustafson, L.B., and Hunt, J.P., 1975, The porphyry copper deposit at El Salvador, Chile: Econ. Geol., v. 70, p.857-912

amilli, R.J., and Ohmoto, H., 1977, Paragenesis, zoning, fluid inclusion, and isotopic studies of the Finlandia vein, Colqui district, Central Peru: Econ. Geol., v. 72, p.950-982.

Kelly, W.C., and Turneaure, F.S., 1970, Mineralogy, paragenesis and geothermometry of the tin and tungsten deposits of the Eastern Andes, Bolivia: Econ. Geol., v, 65, p. 609-680.

andis, G.P., and Rye, R.O., 1974: Geologic, fluid inclusion, and stable isotope studies of the Pasto Bueno tungsten-base metal ore deposit, northern Peru: Econ. Geol., v. 69, p.1025-1059.

Lee, M.A. (ed.), 1970, Proceedings of the Eighth Guyana Geological Conference: Georgetown, 1115 Aug. 1969, Dep. of Geol. and Mines, Georgetown, Guyana.

Lehmann, B., 1979, Schichtgebundene Sn-Lagerstătten in der Cordillera Real/Bolivien: Berliner Geowissenschaftliche Abhandlungen, Reihe A, Band 14, 135p.

Levin, P., and Amstutz, G.C., 1973, Neue Untersuchungen uber schichtgebundene Lagerstätten im zentralen Ost-Peru: Münster. Forsch. Geol. Paläont., H. 31/32, p. 233-259.

acdonald, J.R., 1968, A guide to mineral exploration in Guyana: Guyana, Geol. Surv., Bull., No. $38,91 \mathrm{p}$.

Neil, M., 1979, Brazil's uranium/thorium deposits: Francisco, 126p.

eyer, 1965, An early potassic type of wall-rock alteration at Butte, Montana: Am. Mineralogist, v. 50 , p. $1717-1722$.

gan, B.A., 1972, Metamorphic map of the AppalaChians:

orton, J.J., 1975, Mineral and water resources of South Dakota: U.S. Senate, Comm. on Interior and Insular Affairs, $313 \mathrm{p}$.

Ohnsmann, M., Prutek, W., Thum, R., and Wauschkuhn, A., 1978, Die Lagerstätten Raul und Condestable im mesozoischen KUstengurtel Péru's in ihrem geologischen und mineralogisch-petrographischen Zusammenhang: 6. Geowissenschaftliches Lateinamerika Kolloquium, Stuttgart, Abs. p. 28. deposits of Central Peru: Econ. Geol., v. 60 , p. $407-476$

Petersen, U., 1970, Metallogenic provinces in South America: Geol. Rundschau, B. 59, p. 834-897.

Petersen, U., 1972, Geochemical and tectonic implications of South American metallogenic provinces: Sci., Ann., v.196, art. 1, p. 3-38.

Petersen, U., Noble, D.C., Arenas, M.J., and Goodell, P.C., 1977, Geology of the Julcani Mining District, Peru: Econ. Geol., v. 72, p. 931-949.

Putzer, H., 1962, Geologie von Paraguay: Berlin, Gebr. Borntraeger, $182 \mathrm{p}$.

Putzer, H., 1971, Mineralische rohstoffe in Ecuador, in Geologie von Ecuador, Sauer, W. and Putzer, H., (eds.): Hdb. Region. Geol. d. Erde, v. 11, p. 205-257.

Putzer, H., 1976, Metallogenetische Provinzen in Südamerika: E. Schweizerbart'sche Verlagsbuchhandlung, Stüttgart, $316 \mathrm{p}$.

Reid, A.R., 1974, Proposed origin for Guianian diamonds: Geology, v. 2, p. 67-68.

Ripley, E.M., and Ohmoto, H., 1977, Mineralogic, sulfur isotope, and fluid inclusion studies of the stratabound copper deposits at the Raul Mine, Peru: Econ. Geol., v, 72, p. 1017-1041.

Ripley, E.M., and Ohmoto, H., 1979, Oxygen and hydrogen isotopic studies of ore deposition and metamorphism at the Raul mine, Peru: Geochem. et Cosmochim, Acta, v. 43, p. 1633-1643.

Ruiz Fuller, C., and Aguirre, L., 1965, Geologia y yacimientos metaliferos de Chile: Inst. de Invest. Geol., Santiago, 305 p.

Rye, R.O., and Sawkins, F.J., 1974, Fluid inclusion and stable isotope studies on the Casapalca Ag$\mathrm{Pb}-\mathrm{Zn}-\mathrm{Cu}$ deposits, Central Andes, Peru: Econ. Geol., v. 69, p. 181-205.

Schneider, H.-J., 1975, Ein neues genetisches Konzept für die sogenannte bolivianische Zinn-SilberProvinz: Abstr., Intern. Clausthal-Kolloquium SGA, GDMB \& COM, Clausthal-Zellerfeld, April 1975.

Schulz, G.-G., 1973, Die schichtgebundene Zink=blendelagerstătte San Vicente in Peru: Erzmetall, v. 26, No. 6, p. 284-289.

illitoe, R.H., Halls, C., and Grant, J.N., 1975, Porphyry tin deposits in Bolivia: Econ. Geol., v. 70, p. 913-927.

Tolbert, G.E., 1964, Geology of the Raposos gold mine, Minas Gerais, Brazil: Econ. Geol., v. 59, p. 775-798.

Wauschkuhn, A., 1978, Die Genese der schichtgebundenen Cu-Lagerstätten im mesozoischen KÜstengürtel von Peru: 6. Geowissenschaftliches Lateinamerika Kolloq., Stuttgart, p. 43-44 (Abs.)

Vokittel, R., 1960, Recursos minerales de Colombia: Compilación Estud. Ofic. Colombia, t. X, 393 p.

u, I., and Petersen, U., 1977, Geochemistry of tetrahedrite and mineral zoning at Casapalca, Peru: Econ. Geol., v. 72, p. 993-1016.

Zeil, W., 1964, Geologie von Chile: Gebr. Borntraeger, Berlin, $233 \mathrm{p}$.

ABOUT THE AUTHOR: Professor of Geology at Harvard University, U.S.A., Ulrich Petersen holds as his principal interests the genesis and zoning of hydrothermal ore deposits in the metallogenic provinces of South America. Former Chief Geologist of the Cerro de Pasco Corporation, he has served as consultant for numerous mining companies and governments (including Panama, Bolivia, Indonesia, Peru) and for the OAS. He holds the Order of Merit for Distinguished Service from the Government of Peru for his outstanding contributions to Peruvian Geology. Professor Petersen is currently President of IFSEG, one of IUGS' affiliated organizations.

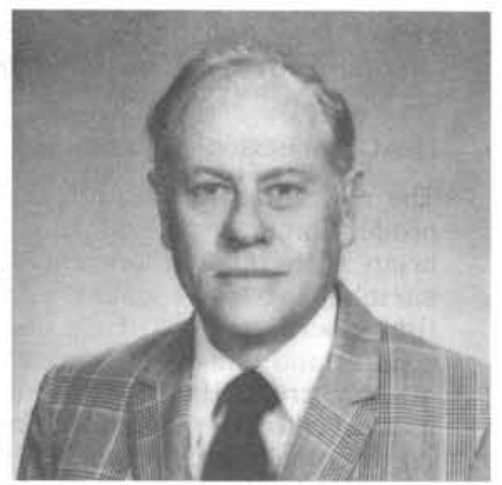

